\title{
ŠKOLSKO POSTIGNUĆE I ZADOVOLJSTVO ŠKOLOM S OBZIROM NA OSOBNE ZNAČAJKE, STRATEGIJE UČENJA I KORIŠTENJE DIGITALNIH MEDIJA U UČENJU
}

\author{
Anela Nikčević-Milković \\ Odjel za nastavničke studije u Gospiću, Sveučilište u Zadru \\ Ulica dr. Ante Starčevića 12, 53000 Gospić \\ amilkovic@unizd.hr
}

\begin{abstract}
Sažetak
Cilj ovog istraživanja bio je ispitati objektivan i subjektivan školski uspjeh učenika s obzirom na neke sociodemografske varijable učenika (dob, obrazovna razina, rod), crte ličnosti, strategije učenja te korištenje digitalnih medija (DM) u učenju i nastavi. Rezultati pokazuju da učenici 6. i 8. razreda osnovne škole imaju viši objektivan školski uspjeh u odnosu na učenike 2. razreda srednje škole te da učenici 6. razreda OŠ više koriste adaptivne strategije dubokog kognitivnog procesiranja informacija (DKP) i maladaptivne strategije površinskog kognitivnog procesiranja informacija (PKP). Učenici 6. i 8. razreda OŠ viši su na osobini Ugodnosti, a veća ugodnost znači i veće zadovoljstvo školom. Ekstravertiraniji su učenici 6. razreda OŠ i 2. razreda SŠ u odnosu na učenike 8. razreda OŠ. Učenice te učenici s višim objektivnim i subjektivnim školskim uspjehom otvoreniji su, ali su ovi potonji i neurotičniji. Učenice, učenici 6. razreda OŠ te učenici s višim objektivnim školskim uspjehom savjesniji su te više koriste adaptivne strategije (meta)kognitivne kontrole učenja (MKK) i DKP. Muški rod učenika, oni s nižim školskim uspjehom te oni koji više koriste strategije DKP i PKP lakše uče uz pomoć DM. Učenici s višim školskim uspjehom i oni većeg zadovoljstva školom, viši na dimenziji Ugodnosti te oni koji više koriste strategije MKK i DKP više koriste DM u nastavi. Stariji učenici te oni koji više koriste strategije DKP i PKP više koriste DM za učenje kod kuće. Za objektivan školski uspjeh kao prvi kriterij sve varijable, osim korištenja DM, pokazale su određeni doprinos te su uspješno objasnile 34\% varijance ovog kriterija. Bolji objektivan školski uspjeh pokazuju mlađi i savjesniji učenici, učenice te oni koji više koriste adaptivne strategije MKK, a manje maladaptivne strategije PKP. Veće zadovoljstvo školom kao drugi kriterij pokazuju mlađi učenici, ugodniji i neurotičniji te oni koji više koriste adaptivne strategije MKK. Korištenje DM nije doprinijelo ni objašnjenju ovog kriterija. Postotak objašnjene varijance ovog kriterija je očekivano manji i iznosi 7\%.
\end{abstract}

Ključne riječi: objektivan i subjektivan školski uspjeh, sociodemografske osobine učenika, crte ličnosti, strategije učenja, korištenje digitalnih medija u učenju i nastavi 


\section{UVOD}

Školsko postignuće ili školski uspjeh učenika često se izjednačuje s pojmom školskog učinka, školske kompetencije, školske sposobnosti i sl. pa se onda i na različite načine operacionalizira. Postupci kojima se unutar vrednovanja školskog uspjeha može utvrđivati uspješnost učenika različiti su te se u pravilu oslanjaju na neki oblik procjenjivanja, testiranja ili mjerenja u najširem smislu, a redovito su praćeni i dodatnim prikupljanjem informacija koje se temelje na kvalitativnim uvidima. Školski uspjeh odnosi se na produkt ili ishod obrazovanja. Općenito je moguće razlikovati najmanje tri skupine obrazovnih ishoda: 1) usvajanje znanja koje treba biti dobro organizirano i lako dostupno, 2) usvajanje strategija rješavanja i analiziranja problema, metakognitivnih strategija i strategija samoregulacije i 3) usvajanje pozitivnih stavova, uvjerenja i emocija (De Corte, 2000). Obrazovni ishodi mogu se mjeriti na individualnoj razini (npr. pomoću prosjeka ocjena) ili na grupnoj razini (npr. prosjek ocjena jednog ili više razreda, prosjek ocjena škole, broj izostanaka). Prosjek ocjena je pokazatelj uspjeha koji je najčešće korišten u istraživanjima u psihologiji obrazovanja. Prosjek ocjena je važan prediktor uspjeha u osnovnoj i srednjoj školi, kao i na fakultetu, a ocjene na fakultetu pokazale su se dobrim prediktorima uspjeha na poslu.

Zadovoljstvo školom je konstrukt koji se slabo istraživao, kao što je i manje istraživanja povezanosti objektivnog školskog uspjeha, zadovoljstva školom i samoregulacije učenja. Zadovoljstvo školom smatra se subjektivnom komponentom školskog uspjeha, dok je školski uspjeh izražen ocjenama objektivna mjera školskog postignuća. Istraživanje Verkuytena i Thijsa (2002) pokazuje da je zadovoljstvo školom povezano s objektivnim školskim postignućima te osjećajem samoefikasnosti učenika. Učenici koji imaju bolja objektivna školska postignuća zadovoljniji su školom jer bolja školska postignuća dovode do većeg osjećaja samoefikasnosti. Prema navedenim autorima, učenice su zadovoljnije školom u odnosu na učenike, što oni objašnjavaju time da su one više okrenute odnosima s drugim ljudima, a škola im nudi više mogućnosti razvijanja bliskih veza s drugima.

Pervin, Cervone i John (2008) navode kako su velikih pet faktora ličnosti osnovne dispozicijske sklonosti, univerzalno se posjeduju te ih svaka osoba ima u određenoj mjeri. McCrae i Costa (2003) navode da faktori imaju biološku osnovu. Svaki pojedinac posjeduje određenu razinu svakog od pet faktora, a ta razina kauzalno utječe na životna iskustva te osobe i na njen konačni psihološki razvoj. Starije odrasle osobe u usporedbi s adolescentima pokazuju niži rezultat na Neuroticizmu, Ekstraverziji i Otvorenosti, a viši na Ugodnosti i Savjesnosti. Tinejdžeri su anksiozniji, brinu o tome hoće li biti prihvaćeni i oko samopoštovanja (viši N), više se druže (viši E), otvoreniji su prema svim vrstama iskustava i eksperimentiranju (viši O), ali su kritičniji i zahtjevniji prema drugim osobama i društvu općenito (niža $U$ ) te su manje savjesni i odgovorni (niža $S$ ), odnosno pojedinci postaju povećano savjesni s dobi. Isti obrazac promjena osobina ličnosti dobiven je u različitim kulturama, bez 
obzira na razlike u kulturalnim, političkim i ekonomskim uvjetima (Pervin i sur., 2008). Ipak, ima istraživača koji iznose dokaze o promjenama osobina ličnosti u odrasloj dobi i značajnoj ulozi društvenih faktora (Helson i Kwan, 2000; Helson, Kwan, John i Jones, 2002). Pervin i sur. (2008) navode da istraživanja osobina ličnosti daju sve više dokaza da se ličnost razvija tijekom cijeloga života kao rezultat interakcije pojedinca s društvenom okolinom. Struktura ličnosti je složenija i manje integrirana u djetinjstvu negoli u odrasloj dobi. Tijekom razvoja, naročito adolescencije, ličnost se može promijeniti. Prvotno zasebne dimenzije ličnosti spajaju se u opsežnije, integriranije kod odrasle osobe. Tatalović Vorkapić (2014) ističe kako je veliki petofaktorski model ličnosti najčešće empirijski potvrđen i da se najviše koristi u okviru istraživanja ličnosti širom svijeta, a Mlačić (2002) još naglašava kako model predstavlja jednu od najznačajnijih teorija ličnosti u 20. stoljeću.

Prema Oxfordu (1990), strategije učenja su operacije koje učenik koristi kako bi si olakšao stjecanje, pohranu ili dosjećanje informacija. One su osnovne komponente kognitivne samoregulacije učenja koja je uz metakognitivnu komponentu empirijski i najistraživanija. Prema Lončarićevu modelu samoregulacije učenja, strategije učenja dijele se na: a) strategije dubokog procesiranja informacija, b) strategije površinskog procesiranja informacija i c) strategije samootežavanja ili samohendikepiranja (učenik izbjegava ili smanjuje trud koji treba uložiti u zadatak, najčešće odlažući ga za krajnji rok) (Lončarić, 2008; 2010). Djevojčice uglavnom imaju proaktivan obrazac samoregulacije učenja, koji uključuje proaktivna uvjerenja o kontroli (trudom se dolazi do uspjeha), veći osjećaj akademske samoefikasnosti, one više koriste proaktivne strategije učenja (ponavljanje, uvježbavanje, kontrolu tijeka i ishoda učenja, elaboraciju, organizaciju, primjenu, transformaciju gradiva, kritičko mišljenje) te motivacijske i organizacijske strategije (postavljanje ciljeva, reguliranje truda, upravljanje vremenom i okolinom). Dječaci su usmjereniji na obrambeni obrazac samoregulacije učenja s naglašenim obrambenim uvjerenjima o kontroli (vanjski čimbenici i stabilne osobine određuju uspjeh), imaju ciljne orijentacije koje se odnose na pokazivanje znanja i vještina kroz natjecanje, pokazivanje vlastitih sposobnosti i izbjegavanje mogućnosti neuspjeha te neakademske ciljeve (npr. želje za socijalnom afirmacijom i izbjegavanjem truda). Pri učenju dječaci su usmjereni na minimalne zahtjeve nastavnika i češće koriste strategije nepovezanog memoriranja, samohendikepiranja, obrambenog pesimizma i vanjskog atribuiranja školskog neuspjeha (Lončarić, 2008). Također, postoje razlike u uporabi strategija učenja s obzirom na dob učenika. Mlađi učenici pokazuju veći potencijal za proaktivnu samoregulaciju učenja (veći osjećaj samoefikasnosti, orijentirani su na proaktivne ciljeve usvajanja znanja i vještina, pri učenju koriste proaktivne strategije) u odnosu na starije. Cijeli niz istraživanja pokazuje da učenici koji rabe navedene adaptivne komponente samoreguliranog učenja imaju bolji objektivan školski uspjeh (izražen školskim ocjenama) (Lončarić, 2010; Nikčević-Milković i Perković, 2000; Rijavec, Raboteg-Šarić i Franc, 1999). Učenici boljeg školskog postignuća manje upotrebljavaju površinsko procesiranje informacija, skloniji su 
dubokom procesiranju informacija i adaptivnijim strategijama učenja. Lošiji učenici skloniji su učiti novo gradivo uglavnom se oslanjajući na njegovo memoriranje, usmjeravajući se samo na ono što misle da će učitelj pitati i ne razmišljajući puno, nego ponavljajući dok im se ne učini da su naučili (Rijavec i sur., 1999).

Digitalni ili suvremeni mediji u nastavi, ako se primjenjuju na odgovarajući način, učenje i poučavanje mogu znatno olakšati i učiniti zanimljivijim (El-Gayar, Moran i Hawkes, 2011). Mnogobrojna istraživanja pokazala su da postupno uvođenje digitalne tehnologije u nastavu učenicima i nastavnicima olakšava učenje i poučavanje (Carpenter, 2000; Nadrljanski, Nadrljanski i Tomašević, 2007; Lisek i Brkljačić, 2013; Topolovčan, Matijević i Dumančić, 2016). Učenici se većinom bolje služe suvremenom tehnologijom od svojih nastavnika i roditelja pa ih se naziva digitalnim urođenicima za razliku od odraslih koji se smatraju digitalnim doseljenicima. Kada se koriste informacijsko-komunikacijske tehnologije (IKT), njihovo je korištenje kreativan i inovativan čin stvaralaštva. IKT je važna za razvoj kognitivnih vještina učenika, stvaranje informacija i ideja, povećanje motivacije učenika za učenje, neovisnost u učenju, kao i povećanje samopoštovanja učenika (Tedla, 2012). Nije važan samo posjed IKT-e, već i razvoj vještina pri njihovu korištenju, razvoj sposobnosti rješavanja problema te razvoj informacijske pismenosti (Nikčević-Milković, 2018). Potreba za razvojem informacijske pismenosti i IKT-e u školskim okruženjima proizlazi iz konstruktivističkog pristupa učenju koji naglašava razvoj znanja kroz osobno iskustvo učenika, samostalnost i aktivnost učenika, poticanje kritičkog mišljenja i eksperimentiranja (Nikčević-Milković, 2018). Jackson i sur. (2006) navode da će IKT-e vjerojatnije poboljšati akademska postignuća ako se koriste kao potpora osnovnim procesima koji vode učenju: aktivnom uključivanju, čestoj interakciji s povratnim informacijama, autentičnosti i vezama sa stvarnim svijetom, kao i produktivnom grupnom radu. Prema Rončević Zubković i sur. (2016), implementacija različitih tehnologija vodi edukacijskim promjenama koje imaju za cilj motivirati učenike i studente za aktivno učenje.

Cilj ovog istraživanja bio je ispitati prosječan školski uspjeh kao objektivnu mjeru školskog postignuća i zadovoljstvo školom kao subjektivnu mjeru školskog postignuća učenika različitih obrazovnih razina i roda s obzirom na njihove osobine ličnosti, uporabu strategija učenja te uporabu digitalnih medija u učenju i nastavi. Zanimljivo je bilo ispitati povezanost ovih varijabli te kako se pomoću prediktora (dob, rod, osobine ličnosti, strategije učenja, uporaba digitalnih medija) mogu predvidjeti prosječan školski uspjeh i zadovoljstvo školom (kao kriteriji). Hipoteze od kojih se krenulo su: 1) samoregulirano učenje, točnije strategije učenja kao najvažniji dio kognitivne komponente samoreguliranog učenja i osobine ličnosti povezane su te samoregulirano učenje predviđa akademsko postignuće učenika $i$ zadovoljstvo školom. Učenici koji su više samoregulirani, odnosno koji koriste adaptivnije strategije učenja imaju bolje akademsko postignuće (engl. GPA) i veće zadovoljstvo školom; 2) osobine ličnosti Savjesnost i Otvorenost snažno su povezane s akademskim postignućem; 3) suvremeni digitalni mediji široko ulaze u školske 
kurikule kako za poučavanje, tako i za učenje. Školski uspjeh pozitivno je povezan s korištenjem suvremenih medija, ali kada je ograničeno na optimalan broj sati. Zadovoljstvo školom je također pozitivno povezano s korištenjem suvremenih medija u nastavi i školi općenito.

\section{METODA}

\section{Sudionici}

U istraživanju je sudjelovalo 412 učenika u dobi od 12 do 16 godina iz šest škola iz različitih dijelova Republike Hrvatske (tri osnovne i tri srednje škole). Učenici su dolazili iz 6 . razreda $(N=99 ; 24 \% ; M$ dob $=12,11 ; S D=0,447$; ženski $=53 ; 54 \%)$ i 8. razreda osnovne škole $(N=103 ; 25 \% ; M$ dob $=14,06 ; S D=0,364$; ženski $=50$; $49 \%)$ te 2 . razreda srednje škole $(N=210 ; 51 \% ; M$ dob $=16,06 ; S D=0,454 ;$ ženski $=87 ; 42 \%)$.

\section{Instrumenti}

Upitnik strategija učenja (SSU) (Lončarić, 2014) predstavlja komponentu samoreguliranog učenja koja se odnosi na (meta)kognitivne strategije. Služi za mjerenje strategija učenja kroz osam subskala grupiranih u tri komponente: 1) $\mathrm{Ci}$ klus (meta)kognitivne kontrole učenja (Ponavljanje i uvježbavanje; Kontrola tijeka i ishoda učenja); 2) Duboko kognitivno procesiranje (Elaboracija; Organizacija; Primjena; Kritičko mišljenje) i 3) Površinsko kognitivno procesiranje (Usmjerenost na minimalne zahtjeve; Memoriranje). Na skali Likertova tipa s 5 stupnjeva sudionici su trebali naznačiti koliko se slažu s pojedinom tvrdnjom: 1 - nikada, 5 - u potpunosti da. Pouzdanost skale izražena Cronbach alphom u ovom istraživanju iznosi zadovoljavajućih 0,88 za cijelu skalu, kao i za pojedine subskale: $\alpha$ prva $=0,88, \alpha$ druga $=0,89$ i $\alpha$ tré́a $=0,81$.

Hrvatska verzija kratke skale 5-faktorskog upitnika ličnosti (Tatalović Vorkapić, 2016) je vrlo ekonomična, kratka skala 5-faktorskih osobina ličnosti (Otvorenost, Neuroticizam, Ekstraverzija, Savjesnost, Ugodnost) koja sadrži 10 tvrdnji. Sudionici odgovaraju na skali od 7 stupnjeva gdje je 1 - ne slažem se, a 7 - slažem se sa svim. Pouzdanost skale izražena Cronbah alphom, prema navedenoj autorici iznosi manjih 0,66 , što je potvrđeno i u ovom istraživanju.

Upitnik uporabe digitalnih medija za učenje (UDMU) (Nikčević-Milković, 2018) ispituje korištenje suvremenih digitalnih medija u učenju i nastavi (za učenje kod kuće, svladavanje određenih školskih predmeta, usvajanje generičkih znanja, pisanje školskih i domaćih uradaka, bogatstvo školskog okruženja IKT-a, korištenje pametnih telefona za učenje i sl.). Upitnik sadrži 23 tvrdnje: osam tvrdnji odnosi se na Olakšano učenje uz pomoć DM (primjer tvrdnje: Volio bih stalno učiti uz pomoć 
$D M$ ), sedam tvrdnji odnosi se na Korištenje DM u nastavi ( $U$ školi na nastavi često koristimo DM) i sedam tvrdnji odnosi se na Korištenje DM za učenje kod kuće (Kod učenja kod kuće koristim računalo). Na Likertovoj skali od 5 stupnjeva sudionici su trebali naznačiti koliko se slažu s pojedinom tvrdnjom: 1 - nikada, 5 - u potpunosti da. Pouzdanost cijele skale izražena Cronbach alphom iznosi 0,78 , a pojedinih subskala: $\alpha$ prva $=0,72, \alpha$ druga $=0,71$ i $\alpha$ treća $=0,70$. U ovom istraživanju također je potvrđena zadovoljavajuća pouzdanost skale: Cronbach alpha za cijelu skalu iznosi 0,84 , a za pojedine subskale: $\alpha$ prva $=0,81, \alpha$ druga $=0,72$ i $\alpha$ treća $=0,65$.

Sociodemografske varijable mjerene u ovom istraživanju su: dob, obrazovna razina, rod, prosječan školski uspjeh (prosjek ocjena općeg školskog uspjeha na kraju prethodnog obrazovnog razdoblja i uspjeha iz školskih predmeta Hrvatski jezik i Matematika) i zadovoljstvo školom (mjereno jednom česticom Sa školom sam zadovoljan/na, na koju sudionici odgovaraju na skali Likertova tipa s 5 stupnjeva, gdje 1 znači - uopće nisam zadovoljan/na do 5 - u potpunosti sam zadovoljan/na).

\section{Postupak}

Uz dopuštenje odgovornih institucija i pasivne dozvole roditelja za sudjelovanje njihove djece $u$ istraživanju, a nakon informiranja o cilju i svrsi istraživanja, učenici su upitnike popunjavali u okviru redovne nastave (oko $35 \mathrm{~min}$ ) anonimno (pod šifrom koja je služila samo za povezivanje pojedinih skala i upitnika). Istraživanje je rađeno u skladu s Etičkim kodeksom istraživanja na djeci (Ajduković i Kolesarić, 2003).

\section{REZULTATI}

Najprije su prikazani rezultati ANOVA-e koji su upozorili na postojanje statistički značajne razlike u mjerenim varijablama s obzirom na obrazovnu razinu. Potom su ispitane korelacije među mjerenim varijablama koje su se uglavnom pokazale značajnim pa je nadalje napravljena hijerarhijska regresijska analiza za kriterije objektivnog i subjektivnog školskog uspjeha.

Tablica 1. Razlika u prosjeku školskih ocjena među učenicima različitih obrazovnih razina

\begin{tabular}{lrcccccc}
\hline & $N$ & $M$ & $S D$ & Min & Max & F-omjer & p-vjerojatnost \\
\hline 6. razred & 99 & 3,82 & 0,861 & 2 & 5 & & \\
8. razred & 103 & 3,77 & 0,916 & 2 & 5 & $\mathbf{1 1 , 0 3}^{* *}$ & 0,01 \\
2. srednje & 210 & 3,32 & 0,704 & 2 & 5 & & \\
\hline
\end{tabular}

$* * p<0,01$ 
Iz Tablice 1 vidi se da je F-omjer statistički značajan $(F=11,03, p<0,01)$, tj. da postoji razlika u prosjeku školskih ocjena među učenicima različitih obrazovnih razina. Post hoc analize, uz korištenje Student Newman-Keulsova testa, pokazale su da učenici 6. i 8. razreda osnovne škole imaju statistički značajno viši školski uspjeh od učenika 2. razreda srednje škole.

Tablica 2. Razlika u procjeni Korištenja dubokog kognitivnog procesiranja informacija (DKP) kao strategije učenja kod učenika različitih obrazovnih razina

\begin{tabular}{lrcccccc}
\hline & $N$ & $M$ & $S D$ & Min & Max & F-omjer & p-vjerojatnost \\
\hline 6. razred & 99 & 3,56 & 0,587 & 2,4 & 4,8 & & \\
8. razred & 103 & 3,34 & 0,670 & 1,6 & 5 & $\mathbf{3 , 5 9 * *}$ & 0,03 \\
2. srednje & 210 & 3,38 & 0,631 & 1,5 & 5 & & \\
\hline
\end{tabular}

$* * p<0,05$

Iz Tablice 2 vidi se da je F-omjer statistički značajan $(F=3,59, p<0,03)$. Post hoc analize, uz korištenje Student Newman-Keulsova testa, pokazale su da učenici 6. razreda statistički značajno više koriste strategije dubokog kognitivnog procesiranja informacija od učenika 8. razreda osnovne škole i 2. razreda srednje škole.

Tablica 3. Razlika u procjeni Korištenja površinskog kognitivnog procesiranja informacija (PKP) kao strategije učenja kod učenika različitih obrazovnih razina

\begin{tabular}{lrcccccc}
\hline & $N$ & $M$ & $S D$ & Min & Max & F-omjer & p-vjerojatnost \\
\hline 6. razred & 99 & 3,04 & 0,887 & 1,2 & 5 & & \\
8. razred & 103 & 2,73 & 0,834 & 1 & 5 & $\mathbf{3 , 7 2 *}$ & 0,03 \\
2. srednje & 210 & 2,83 & 0,842 & 1 & 5 & & \\
\hline
\end{tabular}

$* * p<0,05$

Iz Tablice 3 vidi se da je F-omjer statistički značajan $(F=3,72, p<0,03)$. Post hoc analize uz korištenje Student Newman-Keulsova testa pokazale su da učenici 6. razreda osnovne škole statistički značajno više koriste strategije površinskog kognitivnog procesiranja informacija od učenika 8. razreda osnovne škole i 2. razreda srednje škole. 
Tablica 4. Razlika u procjeni Ekstraverzije kao crte ličnosti kod učenika različitih obrazovnih razina

\begin{tabular}{lrcccccc}
\hline & $N$ & $M$ & $S D$ & Min & Max & F-omjer & p-vjerojatnost \\
\hline 6. razred & 99 & 4,441 & 1,76 & 2 & 7 & & \\
8. razred & 103 & 3,83 & 1,22 & 1 & 7 & $\mathbf{5 , 9 1 * *}$ & 0,00 \\
2. srednje & 210 & 4,14 & 1,22 & 1 & 7 & & \\
\hline
\end{tabular}

$* * p<0,05$

Iz Tablice 4 vidi se da je F-omjer statistički značajan $(F=5,91 ; p<0,00)$. Post hoc analize uz korištenje Student Newman-Keulsova testa, pokazale su da su učenici 6. razreda osnovne škole i 2. razreda srednje škole statistički značajno više ekstravertirani od učenika 8. razreda osnovne škole.

Tablica 5. Razlika u procjeni Savjesnosti kao crte ličnosti kod učenika različitih obrazovnih razina

\begin{tabular}{lrcccccc}
\hline & $N$ & $M$ & $S D$ & Min & Max & F-omjer & p-vjerojatnost \\
\hline 6. razred & 99 & 5,41 & 1,345 & 1,5 & 7 & & \\
8. razred & 103 & 5,01 & 1,273 & 1 & 7 & $\mathbf{3}, 62^{* *}$ & 0,03 \\
2. srednje & 210 & 5,01 & 1,256 & 1 & 7 & & \\
\hline
\end{tabular}

$* * p<0,05$

Iz Tablice 5 vidi se da je F-omjer statistički značajan $(F=3,62 ; p<0,03)$. Post hoc analize uz korištenje Student Newman-Keulsova testa, potvrdile su da su učenici 6. razreda osnovne škole statistički značajno savjesniji u usporedbi s učenicima 8. razreda osnovne škole i 2 . razreda srednje škole.

Tablica 6. Razlika u procjeni Ugodnosti kao crte ličnosti kod učenika različitih obrazovnih razina

\begin{tabular}{lrcccccc}
\hline & $N$ & $M$ & $S D$ & Min & Max & F-omjer & p-vjerojatnost \\
\hline 6. razred & 99 & 5,18 & 1,308 & 1,5 & 7 & & \\
8. razred & 103 & 5,18 & 2,950 & 2 & 7 & $\mathbf{3 , 9 3}^{* *}$ & 0,02 \\
2. srednje & 210 & 4,68 & 1,165 & 1 & 7 & & \\
\hline
\end{tabular}

$* * p<0,05$ 
Iz Tablice 6 vidi se da je F-omjer statistički značajan $(F=3,93 ; p<0,02)$. Post hoc analize, uz korištenje Student Newman-Keulsova testa, pokazale su da su učenici 6. i 8. razreda osnovne škole statistički značajno viših rezultata na osobini Ugodnosti u usporedbi s učenicima 2. razreda srednje škole.

Tablica 7. Spearmanove rang korelacije između sociodemografskih varijabli, prosječnog školskog uspjeha, zadovoljstva školom i crta ličnosti

\begin{tabular}{lccccc}
\hline & Otvorenost & Neuroticizam & Ekstraverzija & Savjesnost & Ugodnost \\
\hline Dob & $-0,13$ & $-0,07$ & $-0,07$ & $\mathbf{- 0 , 1 4 *}$ & $\mathbf{- 0 , 1 2 *}$ \\
Rod & $\mathbf{0 , 1 7 *}$ & $-0,03$ & 0,07 & $\mathbf{0 , 1 9 *}$ & 0,07 \\
Školski uspjeh & $\mathbf{0 , 2 0 *}$ & $\mathbf{0 , 1 4 *}$ & 0,07 & $\mathbf{0 , 3 2 *}$ & 0,03 \\
Zadovoljstvo & $\mathbf{0 , 1 4 *}$ & $\mathbf{0 , 2 0 *}$ & 0,04 & $\mathbf{0 , 1 7 *}$ & $\mathbf{0 , 1 3 *}$ \\
školom & & & & & \\
$* p<0,05$ & & & & &
\end{tabular}

Iz Tablice 7 vidi se da su korelacije između sociodemografskih varijabli, objektivnog i subjektivnog školskog uspjeha te crta ličnosti uglavnom od niskih do umjerenih. Učenice $\left(r_{s}=0,17, p<0,05\right)$, učenici s višim prosječnim školskim uspjehom $\left(r_{s}=0,20, p<0,05\right)$ te oni s većim zadovoljstvom školom $\left(r_{s}=0,14, p<0,05\right)$ značajno su otvoreniji prema novim iskustvima. Učenici s višim prosječnim školskim uspjehom $(r s=0,14, p<0,05)$ te oni s većim zadovoljstvom školom $(r s=0,20$, $p<0,05)$ značajno su više neurotični. Mlađi učenici $(r s=-0,14, p<0,05)$, učenice $(r s=0,19, p<0,05)$, učenici s višim prosječnim školskim uspjehom $(r s=0,32$, $p<0,05)$ te oni s većim zadovoljstvom školom $(r s=0,17, p<0,05)$ značajno su savjesniji. Mlađi učenici $(r s=-0,12, p<0,05)$ te oni s većim zadovoljstvom školom $(r s=0,13, p<0,05)$ značajno su ugodniji.

Iz Tablice 8 vidi se da su korelacije između sociodemografskih varijabli (dob i rod), prosječnog školskog uspjeha, zadovoljstva školom, strategija učenja i korištenja digitalnih medija od niskih do umjerenih. Mlađi učenici $(r s=-0,24, p<0,05)$, učenice $(r s=0,23, p<0,05)$, oni s višim prosječnim školskim uspjehom $(r s=0,33$, $p<0,05)$ te $\mathrm{s}$ većim zadovoljstvom školom $(r s=0,17, p<0,05)$ značajno više koriste adaptivne strategije (meta)kognitivne kontrole učenja (MKK). Učenice $(r s=0,25$, $p<0,05)$ i učenici s višim prosječnim školskim uspjehom $(r s=0,23, p<0,05)$ značajno više koriste adaptivne strategije dubinskog procesiranja informacija (DKP). Učenici s nižim prosječnim školskim uspjehom $(r s=-0,39, p<0,05)$ značajno više koriste maladaptivne strategije površinskog procesiranja informacija (PKP). Muški rod učenika $(r s=-0,13, p<0,05)$ i učenici s nižim prosječnim školskim uspjehom $\left(r_{s}=-0,10, p<0,05\right)$ značajno lakše uče uz pomoć digitalnih medija. Učenici s višim prosječnim školskim uspjehom $(r s=0,10, p<0,05)$ i oni s većim zadovoljstvom 
Tablica 8. Spearmanove rang korelacije između sociodemografskih varijabli, prosječnog školskog uspjeha, zadovoljstva školom, strategija učenja i korištenja digitalnih medija

\begin{tabular}{|c|c|c|c|c|c|c|}
\hline & $M K K$ & $D K P$ & $P K P$ & $\begin{array}{c}\text { Olakšano } \\
\text { učenje uz } \\
\text { pomoć DM }\end{array}$ & $\begin{array}{l}\text { Korištenje DM } \\
\text { u nastavi }\end{array}$ & $\begin{array}{c}\text { Korištenje DM } \\
\text { za učenje kod } \\
\text { kuće }\end{array}$ \\
\hline Dob & $-0,24 *$ & $-0,09$ & $-0,04$ & 0,68 & $-0,08$ & $0,16^{*}$ \\
\hline Rod & $0,23 *$ & $0,25 *$ & $-0,08$ & $-0,13 *$ & 0,05 & $-0,06$ \\
\hline Školski uspjeh & $0,33^{*}$ & $0,23 *$ & $-0,39 *$ & $-0,10^{*}$ & $0,10 *$ & $-0,07$ \\
\hline $\begin{array}{l}\text { Zadovoljstvo } \\
\text { školom }\end{array}$ & $0,17 *$ & 0,08 & $-0,02$ & $-0,00$ & $0,14 *$ & 0,04 \\
\hline
\end{tabular}

Legenda: MKK - Ciklus (meta)kognitivne kontrole učenja; DKP - Strategije dubokog kognitivnog procesiranja informacija; PKP - Strategije površinskog kognitivnog procesiranja informacija; DM - digitalni mediji; * $p<0,05$

Tablica 9. Pearsonove korelacije između crta ličnosti, strategija učenja i korištenja digitalnih medija

\begin{tabular}{lcccccc}
\hline & MKK & DKP & PKP & $\begin{array}{c}\text { Olakšano } \\
\text { učenje uz } \\
\text { pomoć DM }\end{array}$ & $\begin{array}{c}\text { Korištenje DM } \\
\text { u nastavi }\end{array}$ & $\begin{array}{c}\text { Korištenje DM } \\
\text { za učenje kod } \\
\text { kuće }\end{array}$ \\
\hline Otvorenost & $\mathbf{0 , 1 6 *}$ & $\mathbf{0 , 2 2 *}$ & $\mathbf{- 0 , 2 0 *}$ & 0,01 & 0,04 & 0,02 \\
Neuroticizam & 0,07 & 0,05 & $\mathbf{- 0 , 2 2 *}$ & $-0,04$ & 0,05 & $-0,02$ \\
Ekstraverzija & 0,01 & 0,09 & 0,01 & $-0,04$ & 0,00 & 0,01 \\
Savjesnost & $\mathbf{0 , 0 3 *}$ & $\mathbf{0 , 2 6 *}$ & $\mathbf{0 , 0 3 *}$ & $-0,08$ & 0,05 & $-0,06$ \\
Ugodnost & $\mathbf{0 , 1 6 *}$ & $-0,05$ & 0,01 & $-0,02$ & $\mathbf{0 , 1 3 *}$ & $-0,05$ \\
\hline
\end{tabular}

Legenda: MKK - Ciklus (meta)kognitivne kontrole učenja; DKP - Strategije dubokog kognitivnog procesiranja informacija; PKP - Strategije površinskog kognitivnog procesiranja informacija; $* p<0,05$

školom $\left(r_{s}=0,14, p<0,05\right)$ značajno više koriste DM u nastavi, dok stariji učenici $\left(r_{s}=0,16, p<0,05\right)$ značajno više DM koriste za učenje kod kuće.

Iz Tablice 9 vidi se da se korelacije između crta ličnosti, strategija učenja i korištenja digitalnih medija kreću u rasponu od niskih do umjerenih. Otvoreniji učenici više koriste adaptivne strategije (meta)kognitivne kontrole učenja $(r=0,16$, $p<0,05)$ i strategije dubokog kognitivnog procesiranja informacija $(r=0,22$, $p<0,05)$, a manje maladaptivne strategije površinskog kognitivnog procesiranja informacija $(r=-0,20, p<0,05)$. Neurotičniji učenici manje koriste maladaptivne strategije PKP $(r=-0,22, p<0,05)$, dok savjesniji učenici više koriste sve tri vrste strategija učenja: MKK $(r=0,03, p<0,05)$, DKP $(r=0,26, p<0,05)$ i PKP 
Tablica 10. Pearsonove korelacije između strategija učenja i korištenja digitalnih medija

\begin{tabular}{lccc}
\hline & $\begin{array}{c}\text { Olakšano učenje } \\
\text { uz pomoć DM }\end{array}$ & $\begin{array}{c}\text { Korištenje DM } \\
\text { u nastavi }\end{array}$ & $\begin{array}{c}\text { Korištenje DM } \\
\text { za učenje kod kuće }\end{array}$ \\
\hline MKK & 0,04 & $0,15^{*}$ & 0,08 \\
DKP & $\mathbf{0 , 1 4 *}$ & $0,15^{*}$ & $\mathbf{0 , 2 1 *}$ \\
PKP & $\mathbf{0 , 2 1 *}$ & 0,04 & $0,14^{*}$ \\
\hline
\end{tabular}

Legenda: MKK - Ciklus (meta)kognitivne kontrole učenja; DKP - Strategije dubokog kognitivnog procesiranja informacija; PKP - Strategije površinskog kognitivnog procesiranja informacija; DM digitalni mediji; * $p<0,05$

$(r=0,03, p<0,05)$. Ugodniji učenici više koriste adaptivne strategije MKK $(r=0,16, p<0,05)$ te digitalne medije $\mathrm{u}$ nastavi $(r=0,13, p<0,05)$.

Iz Tablice 10 vidi se da su korelacije između strategija učenja i korištenja digitalnih medija u učenju i nastavi u rasponu od niskih do umjerenih. Veće korištenje strategija MKK značajno je povezano s većim korištenjem digitalnih medija u nastavi $(r=0,15, p<0,05)$. Veće korištenje strategija DKP značajno je povezano $\mathrm{s}$ olakšanim učenjem uz pomoć $\mathrm{DM}(r=0,14, p<0,05)$, većim korištenjem $\mathrm{DM} \mathrm{u}$ nastavi $(r=0,15, p<0,05)$ te većim korištenjem DM za učenje kod kuće $(r=0,21$, $p<0,05)$. Veće korištenje strategija PKP značajno je povezano $\mathrm{s}$ olakšanim učenjem uz pomoć DM $(r=0,21, p<0,05)$ te s korištenjem DM za učenje kod kuće $(r=0,14, p<0,05)$.

S obzirom na to da su bivarijantne analize bile značajne, provedena je hijerarhijska regresijska analiza u četiri koraka s različitim sociodemografskim varijablama (dob i rod), crtama ličnosti, strategijama učenja te korištenjem DM za učenje (kao prediktorima) za prosječan školski uspjeh i zadovoljstvo školom (kao kriterijima). Iz Tablice 11 vidi se da su se za kriterij prosječnog školskog uspjeha sve sociodemografske varijable pokazale statistički značajnima te da su uspjele objasniti $15 \%$ ovog kriterija. Značajan prediktor je dob $(\beta=-0,28, p<0,01)$, što znači da učenici niže dobi imaju bolji objektivan školski uspjeh. Značajan prediktor je rod $(\beta=0,25$, $p<0,01)$, što znači da ženski rod ima bolji objektivan školski uspjeh. Kada su u drugom koraku uz sociodemografske varijable dodane još osobine ličnosti, dob je i dalje ostala značajan prediktor $(\beta=-0,25, p<0,01)$, kao i $\operatorname{rod}(\beta=0,21, p<0,01)$ te se osobina Savjesnost $(\beta=0,23, p<0,01)$ pokazala značajnom, što znači da mlađi i savjesniji učenici te učenice imaju bolji objektivan školski uspjeh. Ovaj je set prediktora uspješno objasnio $20 \%$ ovog kriterija. U trećem koraku, uz navedeni set prediktora dodane su još i strategije učenja te su značajni prediktori i dalje ostali $\operatorname{dob}(\beta=-0,25, p<0,01), \operatorname{rod}(\beta=0,16, p<0,01)$ i Savjesnost $(\beta=0,12, p<0,01)$, a uz njih značajnima su se pokazale strategije MKK $(\beta=0,16, p<0,01)$ i PKP $(\beta=-0,34, p<0,01)$. Znači, mlađi i savjesniji učenici, učenice, oni koji više koriste adaptivne strategije MKK, a manje maladaptivne strategije PKP imaju bolji objek- 
Tablica 11. Rezultati hijerarhijske regresijske analize s prosječnim školskim uspjehom i zadovoljstvom školom kao kriterijima te sociodemografskim varijablama, crtama ličnosti, strategijama učenja i korištenjem DM kao prediktorima

\begin{tabular}{|c|c|c|}
\hline & Školski uspjeh & Zadovoljstvo školom \\
\hline Prediktori & $\beta$ & $\beta$ \\
\hline \multicolumn{3}{|c|}{ 1. korak } \\
\hline Dob & $-0,28 * *$ & $-0,13 * *$ \\
\hline Rod & $0,25 * *$ & 0,01 \\
\hline$\Delta \mathrm{R}^{2}$ & 0,40 & 0,13 \\
\hline $\mathrm{R}^{2}$ & 0,16 & 0,02 \\
\hline Usklađeni $\mathrm{R}^{2}$ & 0,15 & 0,01 \\
\hline $\mathrm{F}(3,408)$ & 37,93 & 3,66 \\
\hline \multicolumn{3}{|c|}{ 2. korak } \\
\hline Dob & $-0,25 * *$ & $-0,09$ \\
\hline Rod & $0,21 * *$ & $-0,01$ \\
\hline Otvorenost & 0,03 & $-0,01$ \\
\hline Neuroticizam & 0,03 &, $15 * *$ \\
\hline Ekstraverzija & 0,03 & 0,05 \\
\hline Savjesnost & $0,23 * *$ & 1,00 \\
\hline Ugodnost & $-0,04$ & $0,10 * *$ \\
\hline$\Delta \mathrm{R}^{2}$ & 0,47 & 0,27 \\
\hline $\mathrm{R}^{2}$ & 0,22 & 0,07 \\
\hline Usklađeni R ${ }^{2}$ & 0,20 & 0,06 \\
\hline $\mathrm{F}(5,406)$ & 15,98 & 4,49 \\
\hline \multicolumn{3}{|c|}{ 3. korak } \\
\hline Dob & $-0,25 * *$ & $-0,07$ \\
\hline Rod & $0,16^{* *}$ & $-0,02$ \\
\hline Otvorenost & $-0,01$ & $-0,01$ \\
\hline Neuroticizam & $-0,00$ & $0,16^{* *}$ \\
\hline Ekstraverzija & 0,03 & 0,05 \\
\hline Savjesnost & $0,12 * *$ & 0,08 \\
\hline Ugodnost & $-0,04$ & 0,09 \\
\hline MKK & $0,16^{* *}$ & $0,12 * *$ \\
\hline DKP & 0,04 & $-0,02$ \\
\hline PKP & $-0,34 * *$ & 0,04 \\
\hline$\Delta \mathrm{R}^{2}$ & 0,59 & 0,29 \\
\hline $\mathrm{R}^{2}$ & 0,35 & 0,08 \\
\hline Usklađeni R² & 0,34 & 0,06 \\
\hline $\mathrm{F}(10,401)$ & 21,96 & 3,71 \\
\hline
\end{tabular}




\begin{tabular}{lcc}
\hline & 4. korak & \\
\hline Dob & $-0,24^{* *}$ & $-0,07$ \\
Rod & $0,16^{* *}$ & $-0,03$ \\
Otvorenost & $-0,01$ & $-0,01$ \\
Neuroticizam & $-0,00$ & $0,15^{* *}$ \\
Ekstraverzija & 0,03 & 0,04 \\
Savjesnost & $0,12^{* *}$ & 0,08 \\
Ugodnost & $-0,05$ & 0,06 \\
MKK & $0,16^{* *}$ & 0,12 \\
DKP & 0,04 & $-0,03$ \\
PKP & $-0,34^{* *}$ & 0,04 \\
Olakšano učenje uz DM & $-0,02$ & 0,08 \\
Korištenje DM u nastavi & 0,07 & 0,10 \\
Korišt. DM za učenje kod kuće & $-0,00$ & 0,07 \\
$\Delta \mathrm{R}^{2}$ & 0,60 & 0,31 \\
$\mathrm{R}^{2}$ & 0,36 & 1,00 \\
Usklađeni R ${ }^{2}$ & 0,34 & 0,07 \\
$\mathrm{~F}(13,398)$ & 17,03 & 3,31 \\
\hline$N=412 ; *<0,05 ; * p<0,01$ & & \\
\hline
\end{tabular}

$N=412 ; * p<0,05 ; * * p<0,01$

tivan školski uspjeh. Ovaj je set prediktora uspješno objasnio 34\% ovog kriterija. $\mathrm{U}$ četvrtom koraku dodani su još i prediktori korištenja digitalnih medija te su se značajnima pokazali: $\operatorname{dob}(\beta=-0,24, p<0,01), \operatorname{rod}(\beta=0,16, p<0,01)$, Savjesnost $(\beta=0,12, p<0,01)$, strategije MKK $(\beta=0,16, p<0,01)$ i strategije PKP $(\beta=-0,34$, $p<0,01)$, što znači da mlađi i savjesniji učenici, učenice, oni koji više koriste strategije MKK, a manje strategije PKP imaju bolji objektivan školski uspjeh. Ovaj je set prediktora uspješno objasnio $34 \%$ ovoga kriterija. Za zadovoljstvo školom kao kriterij od sociodemografskih varijabli dob se pokazala značajnim prediktorom ( $\beta=-0,13, p<0,01)$, što znači da su mlađi učenici zadovoljniji školom te ove varijable objašnjavaju samo $1 \%$ ovog kriterija. Dodavanjem crta ličnosti u drugom koraku značajnim prediktorima pokazuju se Neuroticizam $(\beta=0,15, p<0,01)$ i Ugodnost $(\beta=0,10, p<0,01)$, što znači da su neurotičniji i ugodniji učenici više zadovoljni školom. Ovaj set prediktora uspješno objašnjava 7\% ovog kriterija. U trećem koraku dodane su još i strategije učenja te se značajnim prediktorom ponovno pokazao Neuroticizam $(\beta=0,16, p<0,01)$ te strategija MKK $(\beta=0,12, p<0,01)$, što znači da su neurotičniji učenici i oni koji više koriste strategije MKK većeg zadovoljstva školom. Ovaj set varijabli uspješno objašnjava $6 \%$ ovog kriterija. U četvrtom koraku samo je Neuroticizam i dalje ostao statistički značajnim prediktorom $(\beta=0,15$, $p<0,01)$, a cijeli set prediktora uspješno objašnjava $7 \%$ ovog kriterija. 


\section{RASPRAVA}

Cilj ovog istraživanja bio je ispitati objektivan i subjektivan školski uspjeh učenika s obzirom na neke sociodemografske osobine učenika, crte ličnosti, strategije učenja i korištenje digitalnih medija u učenju i nastavi. Kao što se moglo i očekivati, mlađi učenici pokazuju viši objektivan školski uspjeh u odnosu na starije, što je u skladu s nalazima ranijih istraživanja (Grgantov, 2010; Lončarić, 2010; Pavić, 2015). Lončarić (2010) navodi da su stariji učenici više usmjereni na pokazivanje znanja i vještina (tzv. ciljna orijentacija na izvedbu) te neakademske ciljeve, a što se odražava na smanjenje školskog uspjeha. Prelaskom učenika iz srednjeg djetinjstva $\mathrm{u}$ adolescentski razvojni period akademska samoefikasnost opada, a motivaciju za učenjem zamjenjuju drugi interesi koji adolescentima postaju zanimljiviji i izazovniji. Mlađi učenici, također, značajno više koriste adaptivne strategije dubokog kognitivnog procesiranja informacija (DKP), ali i maladaptivne strategije površinskog kognitivnog procesiranja informacija (PKP), što je također u skladu s nalazima ranijih istraživanja (Lončarić, 2010; Nikčević-Milković, Biljan i Jerković, 2014). Korištenje adaptivne strategije DKP pozitivno je povezano kako s objektivnim tako i sa subjektivnim školskim uspjehom. Nalazi Stanišak Pilatuš, Jurčec i Rijavec (2013) pokazuju da s godinama školovanja postoji trend smanjenja ciljne orijentacije na učenje, a povećanja ciljne orijentacije na izbjegavanje truda. Ciljne orijentacije na učenje usko su povezane s odabirom adaptivnih strategija učenja. Od crta ličnosti Ugodnost je veća kod mlađih u odnosu na starije učenike, a Ekstraverzija je veća kod učenika 6. razreda osnovne škole i 2 . razreda srednje škole u odnosu na učenike 8. razreda osnovne škole. U istraživanju je dobivena veća Otvorenost prema novim iskustvima kod učenica te učenika s većim objektivnim i subjektivnim školskim uspjehom. Prema Cazan i Schiopca (2014), Otvorenost i Savjesnost su, uz samoregulaciju učenja, značajni prediktori akademskog uspjeha. Blickle (1996) navodi da je ono što on naziva disciplinom učenja povezano s osobinom Otvorenosti. Prema Komarraju, Karau, Schmecku i Avdicu (2011), Otvorenost i Ekstraverzija pozitivno su povezane s elaborativnim procesiranjem kao strategijom učenja. Veza između Otvorenosti i objektivnog školskog postignuća je medijacijska preko refleksivnog stila učenja. Ovi autori navode da biti intelektualno znatiželjan povećava akademsku izvedbu kada učenik kombinira znanstveni interes sa zamišljenom obradom informacija. Ovo istraživanje pokazuje pozitivnu povezanost Neuroticizma s objektivnim i subjektivnim školskim uspjehom, što je u skladu sa starijim rezultatima istraživanja, dok novija istraživanja ipak pokazuju nekonzistentne rezultate (Poropat, 2009). Veća Savjesnost u ovom istraživanju dobivena je kod učenica, mlađih učenika te onih koji pokazuju bolji objektivan i subjektivan školski uspjeh, što je u skladu s nalazima drugih istraživanja (npr. Chamorro-Premuzic i Furnham, 2009). Savjesnost sadrži osobine poput ustrajnosti, samokontrole i težnje za postignućem, upravo one koje su najvažnije za uspjeh u srednjoj školi i na razini visokog školstva. Ugodnost je također veća kod mlađih učenika te onih koji su zadovoljniji školom. Matešić, Ružić i Matešić (2009) navode kako ugodniji učenici pokazuju karakteri- 
stike kooperativnosti, srdačnosti, altruizma, prijateljske naklonjenosti, velikodušnosti i empatičnosti pa su zbog toga učenici koji se više vole družiti zadovoljniji školom jer im ona to upravo i pruža. Komarraju i sur. (2011) navode kako su Savjesnost i Ugodnost pozitivno povezane osobine s na primjer: analizom i sintezom prilikom učenja, metodički oblikovanim učenjem, ponavljanjem činjenica i elaborativnim procesiranjem, dok je Neuroticizam s njima negativno povezan.

U ovom istraživanju utvrđeno je da mlađa dob učenika, učenice te oni koji imaju viši objektivan i subjektivan školski uspjeh više koriste adaptivne strategije ciklusa (meta)kognitivne kontrole učenja (MKK). Mlađi učenici, učenice te oni koji imaju viši objektivan školski uspjeh više koriste adaptivne strategije dubokog kognitivnog procesiranja informacija (DKP). Nikčević-Milković i sur. (2014) navode da rezultati mnogih istraživanja pokazuju da učenici razvojnog perioda srednjeg djetinjstva koriste adaptivnije strategije učenja u odnosu na učenike adolescentske dobi. Te adaptivne strategije su: veća organizacija učenja, samokontrola učenja, strukturiranje materijala koji se uči, samoevaluacija naučenog gradiva, traženje povratne informacije i dr. Učenici adolescentske dobi, s druge strane, koriste maladaptivne strategije učenja: slabu organizaciju učenja, površnost u izvršavanju obveza, doslovno ponavljanje gradiva, memoriranje i dr. Što se tiče rodnih razlika, učenice su neovisno o dobi bolje adaptirane na školu te pokazuju bolji akademski uspjeh, što potvrđuju rezultati mnogih istraživanja (Pavić, 2015). Međutim, Duckworth i Seligman (2006) navode da istraživanja sustavno pokazuju bolji akademski uspjeh učenica u odnosu na učenike u ranijim godinama obrazovanja kada se školski uspjeh iskazuje školskim ocjenama, ali kada se obrazovno postignuće iskazuje rezultatima na vanjskom vrednovanju, rodne razlike ovise o ispitanom području i dobi učenika. Prema Verkuyten i Thijs (2002), zbog većeg školskog uspjeha i bolje prilagođenosti škole djevojčicama/djevojkama (npr. učenice se lakše identificiraju s nastavnicima jer su oni uglavnom ženskog roda, zahtjevi škole su pristupačniji učenicama i njihovu načinu rada), učenice su i subjektivno zadovoljnije školom u odnosu na svoje muške kolege. Nadalje, u ovom istraživanju utvrđeno je da veća Otvorenost znači veću uporabu adaptivnih strategija ciklusa (meta)kognitivne kontrole učenja (MKK) i dubokog kognitivnog procesiranja informacija (DKP), a manju uporabu maladaptivnih strategija površinskog kognitivnog procesiranja informacija (PKP). Neuroticizam znači manju uporabu maladaptivnih strategija PKP. Savjesnost je pozitivno povezana s korištenjem sve tri vrste kognitivnih strategija učenja, dok je Ugodnost pozitivno povezana s korištenjem adaptivnih strategija MKK. Prema Garrison (1997), samoregulirano učenje treba se promatrati kao proces ili psihološki aspekt koji je uglavnom određen crtama ličnosti. Lounsbury, Levy, Park, Gibson i Smith (2009) navode da su samoregulirano učenje, akademsko postignuće i crte ličnosti usko povezane. Prema Ponton, Derrick i Carr (2005), crte ličnosti su snažan prediktor objašnjenja samoreguliranog učenja. Lounsbury i sur. (2009) navode da upravo Big five model crta ličnosti daje jednu organiziranu shemu za razumijevanje povezanosti između učeničke samoregulacije učenja i crta ličnosti. Cazan i Schi- 
opca (2014) u istraživanju na studentima potvrđuju ovu povezanost te navode da je Otvorenost kao crta ličnosti najjače pozitivno povezana sa svim skalama samoregulacije učenja: (meta)kognitivnim, motivacijskim, emocionalnim, ponašajnim i kontekstualnim strategijama učenja, fazom prije, za vrijeme i nakon učenja (tzv. evaluacija učenja). Samoregulirani učenici su savjesniji, ekstravertiraniji i ugodniji. Međutim, rezultati mnogih istraživanja pokazuju da samoregulirano učenje ne može biti jednostavno objašnjeno crtama ličnosti. Moguće je da crte ličnosti u kombinaciji s drugim aspektima poput ciljne orijentacije u učenju, motivacije, samodeterminacije objašnjavaju veću količinu zajedničke varijance između osobina ličnosti i samoregulacije učenja. Samoregulirano učenje i osobine Savjesnosti i Otvorenosti najviše predviđaju akademsko postignuće. Objašnjenje može ići u smjeru medijacijske povezanosti između crta ličnosti, samoreguliranog učenja i akademskog postignuća. Kokkinos, Kargiotidis i Markos (2015) istražili su prediktivnu povezanost između 5-faktorskog modela crta ličnosti i samoregulacijskih strategija učenja na uzorku od 521 grčkog studenta, budućih učitelja. Visok rezultat na osobini Ekstraverzije i nizak rezultat na osobini Neuroticizma prediktivni su za korištenje ovih strategija, dok osobine Savjesnost, Otvorenost i Ugodnost pokazuju nekonzistentne rezultate. Bidjerano i YunDai (2007) također su istražili povezanost između crta ličnosti prema 5-faktorskom modelu i korištenja samoregulacijskih strategija učenja, kao i njihov doprinos objašnjenju akademskog postignuća na studentima preddiplomskog studija. Njihovi rezultati pokazali su da osobina intelektualne znatiželje ili Otvorenost prema novim iskustvima ima nezavisan doprinos objašnjenju varijance akademskog postignuća, dok regulacija napora posreduje učinke osobina Savjesnosti i Ugodnosti.

U ovom istraživanju utvrđeno je da uz pomoć digitalnih medija lakše uče učenici muškog roda te učenici slabijeg školskog uspjeha. Mlađi učenici te oni s višim objektivnim školskim uspjehom i većim zadovoljstvom školom više koriste digitalne medije u nastavi. Stariji učenici više koriste digitalne medije za učenje kod kuće. Cijeli niz istraživanja potvrđuje povećanje korištenja suvremenih, digitalnih medija s porastom dobi učenika (Ilišin, 2003; Marsh, Brooks, Hughes, Ritchie, Roberts i Wright, 2005). U istraživanju Nikčević-Milković (2018) učenici najviših razreda osnovne škole većinom koriste digitalne medije za čitanje, kao pomoć u učenju matematike te preferiraju obrazovne okoline bogate suvremenim medijima. Njima je domaća zadaća prihvatljivija, lakša i efikasnija kada se izvodi uz pomoć suvremenih medija, a viša školska postignuća postižu kada im je svejedno jesu li im materijali iz kojih uče dizajnirani klasično ili digitalno. Učenici koji svakodnevno koriste digitalne medije, bez obzira na dob, preferiraju njihovo korištenje u razredu, kao i za samostalno učenje kod kuće. Učenici, bez obzira na dob, koji puno vremena koriste računalo lakše uče uz pomoć DM te preferiraju njihovo korištenje za učenje kod kuće. Digitalni mediji također olakšavaju učenje učenicima nižih razreda predmetne nastave te učenicima viših školskih postignuća. Učenicima viših školskih postignuća te muškom rodu učenika DM više koriste za učenje kod kuće. 
Za objektivan školski uspjeh kao kriterij sociodemografske varijable dob i rod pokazale su se statistički značajnima te su uspjeli objasniti $15 \%$ ovog kriterija. Značajan negativan prediktor je dob, što znači da mlađi učenici imaju bolji školski uspjeh, što je bilo očekivano prema rezultatima ranijih istraživanja. Značajan pozitivan prediktor pokazao se rod učenika, što znači da ženski rod ima bolji školski uspjeh u odnosu na muški rod, što je također bilo očekivano. Kada su se sociodemografskim osobinama pridodale crte ličnosti u 2. koraku, dob i rod su i dalje značajni prediktori, a od crta ličnosti značajan pozitivan prediktor je samo osobina Savjesnosti te je ovaj set varijabli uspio objasniti $20 \%$ ovog kriterija. Cijeli niz istraživanja pokazuje važnost osobine Savjesnosti za predviđanje akademskog postignuća. Prema Cazan i Schiopca (2014), upravo su osobine Savjesnosti i Otvorenosti, uz samoregulaciju učenja, značajni prediktori akademskog postignuća. Matešić i sur. (2009) na gimnazijskim učenicima u Republici Hrvatskoj su dobili da učenici koji su ustrajniji i temeljitiji (kao poddimenzije osobine Savjesnosti) imaju bolji akademski uspjeh. U istraživanju Vrdoljaka, Lovaković i Kurtović (2018) dimenzija Savjesnosti, ali i Neuroticizma pokazale su se pozitivnim prediktorima akademske uspješnosti na populaciji hrvatskih učenika. Dimenzija Savjesnosti do sada se u istraživanjima dosljedno pokazivala značajnom osobinom u predviđanju akademskog uspjeha $i$ to posebno na višim razinama obrazovanja (Chamorro-Premuzic i Furnham, 2009). Ova dimenzija u sebi sadrži osobine poput ustrajnosti, samokontrole i težnje za postignućem, koje su najvažnije za uspjeh u srednjoj školi i na razini visokog školstva. U sljedećem, trećem koraku dob je i dalje ostala negativan značajan prediktor, rod pozitivan značajan prediktor, osobina Savjesnosti pozitivan značajan prediktor, dok su se od strategija učenja značajnim prediktorima pokazali: strategije ciklusa (meta)kognitivne kontrole učenja (MKK) kao pozitivan prediktor i strategije površinskog kognitivnog procesiranja informacija (PKP) kao negativan prediktor. Znači, mlađi učenici, učenici ženskog roda, savjesniji učenici te oni koji više koriste adaptivne MKK strategije učenja, a manje maladaptivne strategije PKP imaju bolji objektivan školski uspjeh, što je u skladu s očekivanjima. Ovaj set prediktora uspješno je objasnio 34\% ovog kriterija. U četvrtom koraku dodani su još $i$ prediktori korištenja digitalnih medija u učenju i nastavi te su značajni prediktori i dalje ostali oni iz trećeg koraka, dok prediktori korištenja DM nisu pokazali nikakav doprinos. Postotak objašnjene varijance i dalje je 34\%.

Za zadovoljstvo školom kao kriterij od sociodemografskih varijabli dob se pokazala značajnim negativnim prediktorom, što znači da su mlađi učenici zadovoljniji školom, a ove su varijable uspjele objasniti samo 1\% ovog kriterija. Dodajući crte ličnosti značajnim pozitivnim prediktorima pokazale su se osobine Neuroticizma i Ugodnosti te je postotak objašnjene varijance $6 \%$. Znači, neurotičniji i ugodniji učenici zadovoljniji su školom. U istraživanju Matešić i sur. (2009) na gimnazijskim učenicima u Republici Hrvatskoj također je nađena pozitivna povezanost Ugodnosti i zadovoljstva školom. Ugodniji učenici pokazuju karakteristike kooperativnosti, srdačnosti, altruizma, prijateljske naklonjenosti, velikodušnosti i empatičnosti pa su 
zbog toga učenici koji se više vole družiti zadovoljniji školom jer im ona to upravo i pruža. U istraživanju ovih autora, kao i u ovome, dobivena je pozitivna povezanost Neuroticizma i zadovoljstva školom. Poropat (2009) u svom istraživanju također nalazi pozitivnu povezanost Neuroticizma s objektivnim i subjektivnim školskim uspjehom, što je u skladu sa starijim nalazima, dok novija istraživanja pokazuju nekonzistentne rezultate. U trećem koraku, uz Neuroticizam, kao značajan pozitivan prediktor još se pokazuje i adaptivna strategija MKK, međutim, postotak objašnjene varijance i dalje je 6\%. U četvrtom koraku dodavanjem prediktora koji se odnose na korištenje digitalnih medija u učenju i nastavi, osobina Neuroticizam je ostao jedini značajan pozitivan prediktor, a postotak objašnjene varijance ovog kriterija dosegao je samo $7 \%$.

I na kraju nešto o ograničenjima ovog istraživanja te preporukama za buduća istraživanja. U istraživanju su korištene isključivo mjere samoprocjena, što osim problema zajedničke varijance uvjetovane metodom nosi i rizik od postojanja iskrivljenih i socijalno poželjnih odgovora. Raspon obrazovnih razina mogao bi biti veći u nekim budućim istraživanjima te veći i reprezentativniji uzorci škola, kao i stratificirani uzorci učenika, kako bismo bili sigurni da su u uzorak ušli različiti učenici s obzirom na neke karakteristike (npr. učenici iz grada i sela, različitog socioekonomskog statusa, različitog obrazovanja roditelja, različite veličine škola, dobi, razreda, roda). Bez obzira na ova ograničenja, ovo istraživanje je svojevrstan doprinos rasvjetljavanju povezanosti među ovim vrlo značajnim varijablama objektivnog i subjektivnog školskog uspjeha.

\section{LITERATURA}

Ajduković, M. i Kolesarić, V. (2003). Etički kodeks istraživanja na djeci. Zagreb: Državni zavod za zaštitu obitelji, materinstva i mladeži i Vijeće za djecu Vlade Republike Hrvatske.

Bidjerano, T. i Yun Dai, D. (2007). The relationship between the Big-five model of personality and Self-regulated learning strategies. Learning and Individual Diferencies, 17(1), 69-81.

Blickle, G. (1996). Personality traits, learning stratigies, and performance. European Journal of Personality, 10(5), 337-352. https://doi.org/10.1002/(SICI)10990984(199612)10:5<337::AID-PER258>3.0.CO;2-7

Carpenter, S. (2000). In the digital age experts pause to examine the effects on kids. Monitor on Psychology, 31(11), 48-49.

Cazan, A. M. i Schiopca, B. A. (2014). Self-directed learning, personality traits and academic achievement. Social and Behavioral Sciences, 127, 640-644.

Chamorro-Premuzic, T. i Furnham, A. (2009). Mainly Openness: The relationship between the Big Five personality traits and learning approaches. Learning and Individual Differences, 19(4), 524-529. 
De Corte, E. (2000). Marrying theory building and improvement of school practice: A permanent challenge for instructional pshychology. Learning and Instruction, 10, 249-266.

Duckworth, A. L. i Seligman, M. E. P. (2006.). Self-Discipline Gives Girls the Edge: Gender in Self-Discipline, Grades and Achievement Test Scores. Journal of Educational Psychology, 98(1), 198-208.

El-Gayar, O., Moran, M. i Hawkes, M. (2011). Students' Acceptance of Tablet PCs and Implications for Educational. Educational Technology \& Society, 14(2), 58-70. http:// www.jstor.org/stable/jeductechsoci (5.10.2018.)

Garrison, D. R. (1997). Self-Directed Learning: Toward a Comprehensive Model. Adult Education Quarterly, 48(1), 18-33. https://doi.org/10.1177/074171369704800103

Grgantov, A. (2010.). Samopoštovanje i samoefikasnost učenika s obzirom na spol, dob i osobine ličnosti (Doktorska disertacija). Filozofski fakultet Sveučilišta u Splitu.

Ilišin, V. (2003). Mediji u slobodnom vremenu djece i komunikacija o medijskim sadržajima. Medijska istraživanja, 9(2), 9-34.

Jackson, L. A. von Eye, A., Biocca, F. A., Barbatsis, G., Zhao, Y., Fitzgerald, H. E. (2006). Does home Internet use influence the academic performance of low - income children? Developmental Psychology, 42, 429-439.

Helson, R. i Kwan, V. SY (2000). Personality development in adulthood: The broad picture and processes in one longitudinal sample. Advances in Personality Psychology, 1, 77 106.

Helson, R., Kwan, V. SY, John, O.P. i Jones, C. (2002). The growing evidence for personality change in adulthood: Findings from research with personality inventories. Journal of Research in Personality, 36(4), 287-306.

Kokkinos, C. M., Kargiotidis, A. i Markos, A. (2015). The relationship between learning and study strategies and big five personality traits among junior university teachers. Learning and Individual Differences, 43, 39-47. doi: 10.1016/j.lindif.2015.08.031

Komarraj, M., Karau, S. J., Schmeck, R. R. i Avdic, A. (2011). The Big Five personality traits, learning styles, and academic achievement. Personality and Individual Differences, 51, 472-477. doi:10.1016/j.paid.2011.04.019

Lisek, J. i Brkljačić, T. (2013). Tko nam to dolazi? Korištenje informacijske i komunikacijske tehnologije (ICT) i stilovi učenja kod novoupisanoga naraštaja studenata FER-a [Who is this coming to us? Use of information and communication technology (ICT) and learning styles in the newly-born generation of FER students]. Vjesnik bibliotekara Hrvatske, 55, 29-52.

Lončarić, D. (2008). Uloga samoreguliranog učenja u održivom razvoju obrazovanja. U V. Uzelac i L. Vujičić (Ur.), Cjeloživotno učenje za održivi razvoj (str. 191-196). Rijeka: Učiteljski fakultet.

Lončarić, D. (2010). Spol i dob kao odrednice samoreguliranog učenja za cjeloživotno obrazovanje. U: Bacalja, R. (Ur.), Zbornik radova s međunarodnog znanstveno-stručnog skupa Perspektive cjeloživotnog obrazovanja učitelja i odgojitelja (str. 104-118). Zadar: Sveučilište u Zadru. Dostupno na: http://sites.google.com/site/loncaricd/Home/hr/ hr-bib

Lončarić, D. (2014). Motivacija i strategije samoregulacije učenja: teorija, mjerenje i primjena. Sveučilište u Rijeci: Učiteljski fakultet u Rijeci. 
Lounsbury, J. W., Levy, J. J., Park, S. H., Gibson, L. W. i Smith, R. (2009). An Investigation of the Construct Validity of the Personality Trait of Self-Directed Learning. Learning and Individual Differences, 19, 411-418. http://dx.doi.org/10.1016/j.lindif.2009.03.001

Marsh, J., Brooks, G., Hughes, J., Ritchie, L., Roberts, S. i Wright, K. (2005). Digital beginnings: Young children's use of popular culture, media and new technologies. Literacy Research Centre University of Sheffield.

Matešić, K., Ružić, V. i Matešić, K. ml. (2009). Odnos između osobina ličnosti mjerenih BFQ upitnikom i školskog uspjeha učenika gimnazija. Odgojne znanosti, 11(1), 171181.

McCrae, R. R. i Costa, P. T., Jr. (2003). Personality in Adulthood: A Five-factor Theory Perspective (2nd ed.). New York, NY, US: Guilford Press. http://dx.doi. org/10.4324/9780203428412

Mlačić, B. (2002). Leksički pristup u psihologiji ličnosti: pregled taksonomije opisivača osobina ličnosti. Društvena istraživanja, 11, 2-3 (58-59), 553-576.

Nadrljanski, Đ., Nadrljanski, M. i Tomašević, M. (2007). Digitalni mediji u obrazovanju - pregled međunarodnih iskustava. U: 1. međunarodna znanstvena konferencija The Future of Information Sciences: INFuture2007 - Digital Information and Heritage, Zagreb.

Nikčević-Milković, A. i Perković, L. (2000). Uporaba kognitivnih strategija učenja u djece različitog školskog uzrasta. Život $i$ škola, 46(3), 76-93.

Nikčević-Milković, A., Biljan, E. i Jerković, A. (2014). Povezanost komponenti samoregulacije učenja sa školskim uspjehom i zadovoljstvom sa školom. Napredak, 155(4), 375 -398 .

Nikčević-Milković, A. (2018). Use of Digital Media in Learning in Order to Develop Information Literacy. U: Tatković, N., Suran, F. i Diković, M. (Ur.), Reaching Horizons in Contemporary Education (pp 217-246). Juraj Dobrila University of Pula, Faculty of Educational Sciences, Pula, Croatia.

Oxford, R. L. (1990). Language learning strategies. U. A. Burns i J. C. Richards (Ur.), Learning English as a Second Language. Cambridge University Press.

Pavić, J. (2015). Uloga osobina ličnosti i razredno-nastavnog ozračja u objašnjenju školskog uspjeha učenika (Neobjavljeni diplomski rad). Sveučilište u Splitu: Filozofski fakultet. https://urn.nsk.hr/urn:nbn:hr:172:522431

Pervin, L. A., Cervone, D. i John, O. P. J. (2008). Psihologija ličnosti: teorije i istraživanja. Zagreb: Školska knjiga.

Ponton, M. K., Derrick, M. G. i Carr, P. B. (2005). The Relationship between Resourcefulness and Persistence in Adult Autonomous Learning. Adult Education Quarterly, 55(2), 116-128. https://doi.org/10.1177/0741713604271848

Poropat, A. E. (2009). A meta-analysis of the five-factor model of personality and academic performance. Psychological Bulletin, 135(2), 322.

Rijavec, M., Raboteg-Šarić, Z. i Franc, R. (1999). Komponente samoreguliranog učenja i školski uspjeh. Društvena istraživanja, 8, 4-42, 529-541.

Rončević Zubković, B., Kolić-Vehovec, S., Kalebić Maglica, B., Smojver-Adžić, S., Pahljina-Reinić, R. (2016). Attitudes of students and parents towards ICT with regard to the experience of using the iPad in classroom. Suvremena psihologija, 19(1), 37-47. 
Stanišak Pilatuš, I., Jurčec, L. i Rijavec, M. (2013). Ciljne orijentacije u učenju: dobne i spolne razlike i povezanost sa školskim uspjehom. Napredak, 154(4), 473-491.

Tatalović Vorkapić, S. (2016). Ten Item Personality Inventory: A Validation Study of a Croatian Adult Sample. The European Proceedings of Social \& Behavioural Sciences. http:// dx.doi.org/10.15405/epsbs.2016.05.20

Tedla, B. (2012). Understanding the importance, impacts and barriers of ICT on teaching and learning in East African countries. International Journal for e-Learning Security (IJeLS), 2(3/4), 199-207.

Topolovčan, T., Matijević, M. i Dumančić, M. (2016). How Mobile Learning Can Change Education. Online International Interdisciplinary Research Journal, 6, 31-37.

Verkuyten, M. i Thijs, J. (2002). School Satisfaction of Elementary School Children: The Role of Performance, Peer Relations, Ethnicity and Gender. Social-Indicators Research, 59(2), 203-228.

Vrdoljak, G., Lovaković, I. i Kurtović, A. (2018). Personality traits, goal orientations and School Achievement. Primjenjena psihologija, 11(3), 325-344. doi: 10.19090/ pp.2018.3.325-344.

\title{
SCHOOL ACHIEVEMENT AND SCHOOL SATISFACTION CONSIDERING PERSONAL CHARACTERISTICS, LEARNING STRATEGIES AND THE USE OF DIGITAL MEDIA IN LEARNING
}

\begin{abstract}
The aim of this study was to examine students' school achievement and school satisfaction with respect to some sociodemographic variables of learners (age, educational level, gender), personality traits, learning strategies and the use of digital media in learning and teaching. The results show that primary school students of 6th and 8th grade have higher objective school achievement compared to 2 nd grade high school students and that 6th grade primary school students more frequently use the adaptive Deep Cognitive Information Processing Strategies (DKP) and the low-adaptive Surface Cognitive score higher in the personality traits of Comfort, and greater comfort means greater satisfaction with school. The 6th grade primary school and 2 nd grade high school students are more Extraverted compared to 8th grade primary school students. Female students and students with higher objective and subjective school success are more Open, but the latter are aslo more Neurotic. Female students, students of the 6th grade and students with higher objective school achievements are more Conscientious and they use the adaptive learning strategies of (Meta)cognitive Learning Control (MKK) and DKP more frequently. Male students, students with lower school achievement and those who use more DKP and PKP learning strategies learn easier more easily with digital media. Students with higher school achievement and greater satisfaction with school are higher on the dimension of Comfort and those who use the MKK and DKP learning strategies use digital media in teaching more often. Older students and those who use more DKP and PKP learning strategies use digital
\end{abstract}


media more to learn at home. For Objective school achievement as the first criterion, all variables, apart from the use of digital media, have shown a certain contribution and have successfully explained $34 \%$ of the variance of this criterion. Younger and more Conscientious students, female students and those who use more adaptive MKK learning strategies, and less maladaptive PKP learning strategies show better objective school achievement. Greater Satisfaction with school as a second criterion is shown by younger students, more Comfort and more Neurotic students and those who use more adaptive MKK learning strategies. The use of digital media did not contribute to the explanation of this criterion either. The percentage of explained variance of this criterion was expected to be lower and is $7 \%$.

Key words: objective and subjective school success, sociodemographic characteristics of students, personality traits, learning strategies, use of digital media in learning and teaching

Primljeno: 21. 03. 2019. 